\title{
Isolation of Heat Resistant Fungi in Industrialized Orange and Grape Nectars Marketed in the State of Rio de Janeiro, Brazil.
}

\author{
Verônica Leite de Holanda (I), Karen Signori Pereira (I) \\ (I) UFRJ - Universidade Federal do Rio de Janeiro (Av. Athos da Silveira Ramos, 149 - Prédio \\ do CT - Bloco E)
}

\section{Resumo}

Introduction. The feeding is a major concern of the XXI century, and in recent decades, the consumption of food products with more healthful properties and associated with decreased risk of serious illness and death, has been the focus of many people, which led to increased demand for fruit-based beverages. In this new food scenario, the drink industries invest in diversifying its product line by introducing products such as fruit nectar, which is accompanied by concern about possible contaminants and / or spoilage, such as heat resistant fungi, which can survive the process of heat treatment of such products. This study examined the presence of heat resistant molds in industrialized orange and grape nectars marketed in the State of Rio de Janeiro, Brasil. Material and Methods. Samples of nectars: were analyzed four brands of orange and grape nectars and two brands of mixed grape and apple nectar. Isolation of heat resistant fungi: the nectars were subjected to heat shock in a water bath at $80^{\circ} \mathrm{C} / 30 \mathrm{~min}$, followed by cold bath $\left(0^{\circ} \mathrm{C}\right)$, incubated in flasks and plated directly on solid medium based on potato dextrose at $30^{\circ} \mathrm{C} / 30$ days. Gender identification of thermo resistant fungal isolates: isolates are being identified through observation and description of their macroscopic and microscopic characteristics. Comparison of fungi found with those described in the literature: after identification of the isolates, these are compared with data obtained from research in the literature. Discussion of results. Among the 45 samples, three colonies were found on plates with 3 different filamentous aspect in 3

\footnotetext{
Referência:

Verônica Leite de Holanda (I), Karen Signori Pereira (I). Isolation of Heat Resistant Fungi in Industrialized Orange and Grape Nectars Marketed in the State of Rio de Janeiro, Brazil.. In: Anais do 12ㅇ Congresso Latinoamericano de Microbiologia e Higiene de Alimentos - MICROAL 2014 [= Blucher Food Science Proceedings, num.1, vol.1]. São Paulo: Editora Blucher, 2014. 
different nectar marks, marks $\mathrm{B}$ and $\mathrm{D}$ of grape flavor, with colonies beige and green olive, respectively, and the mark $\mathrm{C}$ a mixed of grape and apple, with beige colony. These results corroborate data reported in the literature. Conclusion. According to these results, we conclude the importance of quality control in the manufacturing process of these nectars for your marketing.

Palavras-Chave: nectars, heat resistant fungi, orange, grape, Brazil Agência de Fomento: 